\section{Investigation the Effect of Low, Medium and High Dose of X-Radiation on the Expression of E-cadherin in Colorectal Cancer Cell Line}

\author{
Soleymanifard Sh. ${ }^{10}$, Rostamyari M. ${ }^{2}$, B. Rassouli F. ${ }^{3}$, Meh- \\ dizadeh A. R. ${ }^{4 *(1)}$
}

\begin{abstract}
Background: Radiotherapy has become a part of therapeutic process of more than 50 percent of patients suffering from cancer. However, recent studies have shown that radiation therapy might affect the expression of adhesive molecule related genes such as E-cadherin and cause cancer cells to move and migrate. Besides, various studies have reported that the expression of E-cadherin changes differently after radiation treatment. There are several studies which showed the loss of E-cadherin function after radiation; however, this reduction has not been observed in others.
\end{abstract}

Objective: This study aims to investigate the effect of different radiation doses of $\mathrm{X}$-ray on changes that might occur in the expression of E-cadherin gene in colorectal cancer cell line HT-29.

Material and Methods: In this experimental study, the cells cultured in flasks were irradiated with X- rays in different doses, including $0.1,2.5,5$, and $10 \mathrm{~Gy}$; then, the expression of E-cadherin gene was measured using real-time PCR.

Results: The expression of E-cadherin did not change significantly in post-irradiated HT-29 cell line after different radiation doses of X-ray.

Conclusion: The results showed that low, medium and high doses of $\mathrm{X}$ - radiation did not change the expression of E-cadherin gene in HT-29 cancer cells. However, it has been reported that radiation mostly downregulated the expression of E-cadherin and mediated metastasis formation and invasiveness in different cancer cell lines. Therefore, further studies need to be conducted to investigate the effects of radiation dose on the molecular pathways contributing to regulation of E-cadherin in HT-29 cell line.

Citation: Soleymanifard Sh, Rostamyari M, B. Rassouli F, Mehdizadeh AR. Investigation the Effect of Low, Medium and High Dose of X-Radiation on the Expression of E-cadherin in Colorectal Cancer Cell Line. J Biomed Phys Eng. 2021;11(1):1-8. doi: 10.31661/jbpe.v0i0.2001-1051.

\section{Keywords}

Radiation; Colorectal Cancer; E-cadherin; Real-Time PCR; X-Rays; Radiation Dosage

\section{Introduction}

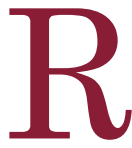
adiation therapy has become a part of therapeutic process of more than 50 percent of patients suffering from cancer $[1,2]$. ower, according to recent clinical and experimental studies, ionizing radiation might induce invasion and enhance metastasis potential in cancer cells [3-8]. One possible mechanism for cancer cells to acquire invasive feature and metastasis potential is loss of cell-cell
${ }^{1}$ PhD, Medical Physics Research Center, Mashhad University of Medical Science, Mash-

had, Iran

${ }^{2} \mathrm{MSc}$, Department of

Medical Physics and

Engineering, School of

Medicine, Shiraz Univer-

sity of Medical Science,

Shiraz, Iran

${ }^{3} \mathrm{PhD}$, Novel Diagnos-

tics and Therapeutics

Research Group, Insti-

tute of Biotechnology,

Ferdowsi University of

Mashhad, Mashhad,

Iran

${ }^{4} \mathrm{MD}, \mathrm{PhD}$, lonizing and

non-Ionizing Radiation

Protection Research

Center, Shiraz Univer-

sity of Medical Science,

Shiraz, Iran

*Corresponding author:

A. R. Mehdizadeh

lonizing and non-lonizing

Radiation Protection

Research Center, Shiraz

University of Medical Sci-

ence, Shiraz, Iran

E-mail: mehdizade@

sums.ac.ir

Received: 13 January 2020 Accepted: 17 March 2020 
adhesion and cell-extracellular matrix interaction [9-11]. Adhesion molecules, which mediates the interaction between cell-cell and cell-extracellular matrix, have a central role in different physiological and also pathological mechanisms [9]. A calcium-dependent adhesion molecule, E-cadherin, mediates $\mathrm{Ca}^{2+}$-dependent hemophilic interaction which is essential for establishment and maintenance of different junctional structures, including tight junctions, adherent-type junctions and desmosomes. These junctions are crucial for epithelial cells to interconnect $[12,13]$. According to different studies, E-cadherin's adhesion function is lost during the most epithelial cancers, including colon, prostate, esophagus, kidney, breast, skin, liver and lung $[10,13]$. Decreased E-cadherin function in cancer cells correlates with de-differentiation, tumor development, invasion and metastasis [13]. Besides, loss of epithelial markers, including E-cadherin, might induce epithelial-mesenchymal transition (EMT) which causes a pro-metastatic properties and promotes stem-like phenotype in cancer cells $[14,15]$. The possible mechanisms explaining the reduction of E-cadherin expression in cancer cells are: mutation of E-cadherin gene, chromatin rearrangements, hypermethylation and loss of trans-factor binding $[10,13,16]$. Moreover, recent studies have shown that radiation therapy might reduce E-cadherin gene and cause cancer cells to move and migrate. However, as summarized in Table 1, various studies have reported that the expression of E-cadherin changes differently after radiation treatment. There are several studies which claimed the loss of Ecadherin function after radiation therapy was

Table 1: Expression of E-cadherin gene in different Post-irradiated cells with various doses of X-ray

\begin{tabular}{|c|c|c|c|c|c|c|}
\hline $\begin{array}{l}\text { Cell line I } \\
\text { Tissue }\end{array}$ & Origin & Radiation & $\begin{array}{l}\text { Dose } \\
\text { Rate }\end{array}$ & Assay & $\begin{array}{l}\text { E-cadherin } \\
\text { expression }\end{array}$ & Ref. \\
\hline A549 & $\begin{array}{l}\text { Human Lung } \\
\text { Cancer }\end{array}$ & $\begin{array}{c}\text { X-ray (2-15 Gy) } \\
0.98 \text { Gy/min }\end{array}$ & $0.98 \mathrm{~Gy} / \mathrm{min}$ & Immunoblot & $\uparrow$ & [17] \\
\hline T-Scc & $\begin{array}{l}\text { Human squamous } \\
\text { cell Carcinoma }\end{array}$ & X-ray (2-10 Gy) & $0.98 \mathrm{~Gy} / \mathrm{min}$ & Immunoblot & $\uparrow$ & [18] \\
\hline A549 & $\begin{array}{l}\text { Human Lung } \\
\text { Cancer }\end{array}$ & $\begin{array}{c}\text { X-ray (10, } 20 \text { Gy) } 5 \\
\text { FR \&10 FR }\end{array}$ & $200 \mathrm{cGy} / \mathrm{min}$ & Real time PCR & --- & [19] \\
\hline HT-29 & Colorectal Cancer & X-ray (10 Gy) $5 \mathrm{FR}$ & $200 \mathrm{cGy} / \mathrm{min}$ & Real time PCR & $\downarrow$ & [19] \\
\hline $\begin{array}{l}\text { CaR1 } \\
\text { DLD1 }\end{array}$ & Colorectal Cancer & X-ray $5 \mathrm{~Gy}$ & & Real time PCR & $\downarrow$ & [3] \\
\hline $\begin{array}{l}\text { Siha } \\
\text { C33A }\end{array}$ & Human Cervical & $\begin{array}{c}\text { X-ray (7 5Gy; } 2 \text { Gy, } \\
5 \text { times/weeks) }\end{array}$ & $0.36 \mathrm{~Gy} / \mathrm{min}$ & Real time PCR & $\downarrow$ & [20] \\
\hline${ }^{*}$ Eca109R & Human ESC & X-ray (4-8 Gy) & $200 \mathrm{cGy} / \mathrm{min}$ & Real time PCR & $\downarrow$ & [21] \\
\hline MCF7 & Breast Cancer & X-ray (20 Gy) 20 & $0.4 \mathrm{~Gy} / \mathrm{min}$ & Real time PCR & $\downarrow$ & [22] \\
\hline NIH3T3 & Mouse Fibroblast & FR \& 10 FR & 0.4 5y/1101 & near unte ren & $\downarrow$ & {$[<4]$} \\
\hline
\end{tabular}

ESC: Esophageal Squamous Carcinoma

FR: Fraction

PCR: Polymerase chain reaction

*Radio resistant Eca109 cell line was established by exposing Eca109 cells to 25 doses of 2 Gy 
Radiation Dose and E-cadherin Expression

followed by EMT transition, metastasis and cancer stem cell induction in residual cancer cells; however, this reduction has not been observed in others [3, 17-22]. Various radiation process, accumulative dose, dose rate might lead to this discrepancy. Owing to this difference, the present study aims to investigate the effect of different radiation doses on changes occurring in the expression of E-cadherin gene in colorectal cancer cell line HT-29.

\section{Material and Methods}

\section{Cell line and cell culture}

In this experimental study, the colorectal cell line, HT-29 provided from Pasteur Institute (Tehran, Iran), were grown in Roswell Park Memorial Institute 1460 (Bioidea) supplemented with $10 \%$ fetal bovine serum (Gibco), $100 \mathrm{u} / \mathrm{ml}$ penicillin and $100 \mu \mathrm{g} / \mathrm{ml}$ streptomycin. The cells were incubated at a humidified $5 \% \mathrm{Co}_{2}$ atmosphere at $37^{\circ} \mathrm{C}$. The medium was renewed every 2 days and the cell was subcultured using $0.25 \%$ trypsin- $0.5 \mathrm{mM}$ EDTA solution, whenever required.

\section{Irradiation}

HT-29 cells were plated in the $12.5 \mathrm{~cm}^{2}$ tissue culture flask. $70 \%$ confluent cells were irradiated with various single doses of x-ray, including 0.1, 2.5, 5 and $10 \mathrm{~Gy}$, emitted from an X-ray unit (Philips, serial number 2.625, Netherland, dose rate: $1.365 \mathrm{~Gy} / \mathrm{min}$ with $100 \mathrm{kVp}$ and $8 \mathrm{~mA}$ ) at room temperature. The cells, which received no radiation, were used as a control group.

\section{RNA Extraction}

Total cellular RNA was extracted from irradiated cells and their relevant group, $20 \mathrm{~h}$ after radiation according to manufacturer's instruction (Yekta Tajhiz Azma Kit, Tehran, Iran). The extracted RNA was then checked for concentration, purity and integrity using nanodrop ${ }^{\circledR}$ spectrophotometer (Thermo Scientific) and agarose gel electrophoresis. To avoid DNA contamination, extracted RNAs were treated with RNAs-free DNase I (Thermo Scientific kit, Massachusetts, USA) and inactivated by EDTA.

\section{cDNA Synthesis}

To synthesis cDNA, Suprime Script RTase, Oligo-dT and dNTPs (GeNet Bio, Korea) were reversely transcribed according to the manufacturer's instructions. The cDNA samples then were stored at $-20{ }^{\circ} \mathrm{C}$ until further processes. The fidelity of synthesized cDNA was then confirmed by polymerase chain reaction (Ampliqon Taq DNA polymerase Master Mix RED kit, Denmark) using GAPDH primers. The final products were loaded on 2\% agarose gel for electrophoresis (Figure 1). Cycling conditions were as follows: initial denaturation at $95^{\circ} \mathrm{C}$ for $5 \mathrm{~min}$, followed by 40 cycles of denaturation at $95^{\circ} \mathrm{C}$ for $30 \mathrm{~s}$, annealing at $58{ }^{\circ} \mathrm{C}$ for $30 \mathrm{~s}$, extension at $72{ }^{\circ} \mathrm{C}$ for $30 \mathrm{~s}$ and final extension for $5 \mathrm{~min}$ at $72^{\circ} \mathrm{C}$.

\section{Quantitative real-time PCR}

Finally, the Ampliqon SYBER Green PCR kit (Denmark) was used to perform real-time polymerase chain reaction (real-time PCR). Light Cycler 96 System (Roche, Basal, Switzerland) was used to perform real-time PCR. To study the expression of E-cadherin, the following specific primers were used;

GAPDH: forward, 5'- GACCACTTTGTCAAGCTCATTTCC -3';

Reverse, $5^{\prime}-$

GT-

\section{GAGGGTCTCTCTCTTCCTCTTGT-3';}

E-cadherin: forward, 5'- ACATATCGGATTTGGAGAGACACT -3';

\section{Reverse, 5'- CAACTGGAGAACCATT-} GTCTGTAG -3';

The CT number of E-cadherin was normalized to GAPDH in each sample. PCR efficiency was measured for the gene of interest using Linreg PCR software, and relative changes for mRNA level were calculated based on the $\Delta \Delta \mathrm{Ct}$ method. 


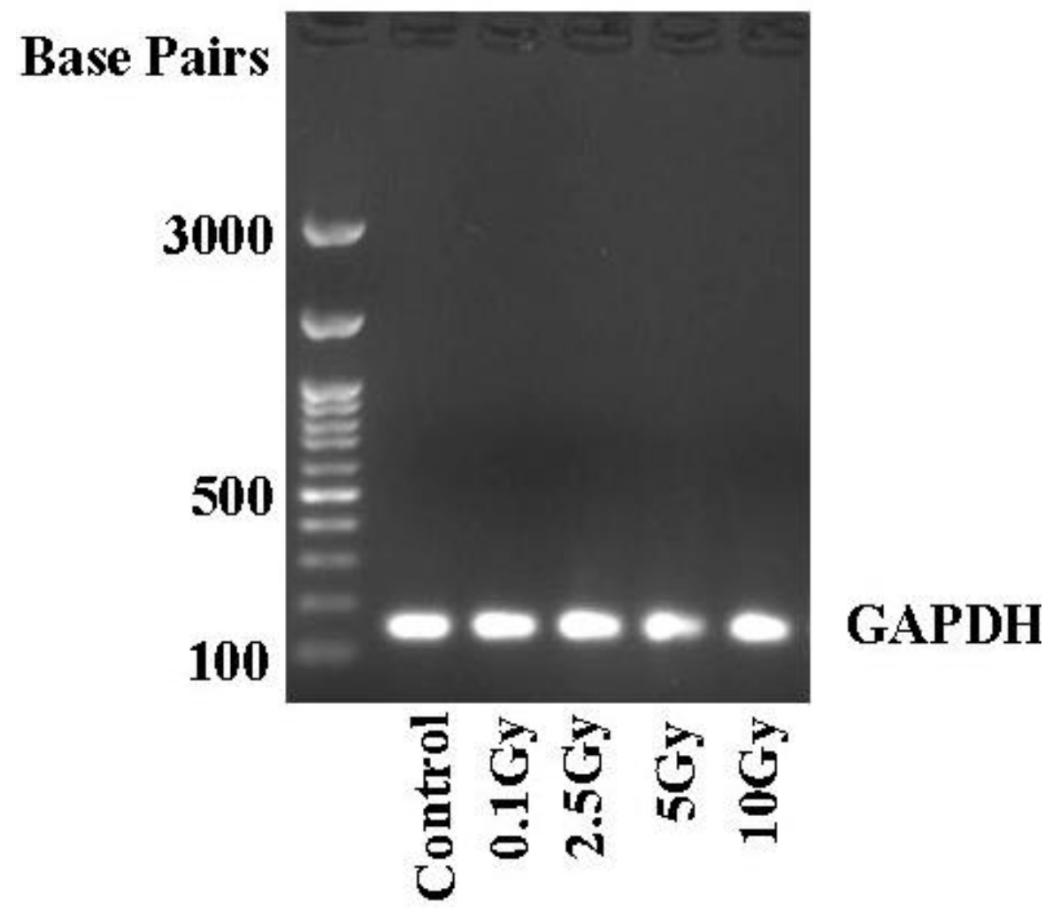

Figure 1: Gene expression pattern of GAPDH primers in post-irradiated HT-29 cell line and their relevant control group.

\section{Statistical analysis}

The data were statistically analyzed by oneway ANOVA using Graph Pad Prism version 8.0. Results were reported as mean $\pm \mathrm{SD}$ and $\mathrm{P}<0.05$ was considered to be statistically significant.

\section{Results}

Expression of EMT gene, E-cadherin, after exposing to different doses of X-ray

According to the data shown in Figure 2, different doses of X-ray $(0.1,2.5,5$ and $10 \mathrm{~Gy})$ did not change the expression of E-cadherin gene in HT-29 cells significantly $(\mathrm{p}>0.05)$.

\section{Discussion}

Radiotherapy is one of the most important modalities for cancer treatment. However, according to recent clinical and experimental studies, ionizing radiation might induce invasion and enhance metastasis potential in cancer cells [3, 8, 19, 20, 23, 24]. Moreover, recent studies have demonstrated that changes undergoing in cell-cell adhesion and cell-extracellular matrix interaction in post-irradiated tumor cells might cause them to loss their epithelial characters and acquire mesenchymal morphology which lead to enhanced potential for migration, invasion and metastasis $[9,18$, 22]. Therefore, overcoming the enhancement of metastatic potential through adhesion molecules after radiation treatment is an important issue. Among different adhesion molecules, dysfunction of E-cadherin, with a key role for establishment and maintenance of different junctional structures, has been recognized in various physiological and pathological diseases including cancer $[10,11,25,26]$. Several studies demonstrated that the expression of Ecadherin decreases after radiation and causes cancer cells to acquire metastasis potential; On the other hand, there are a few research- 


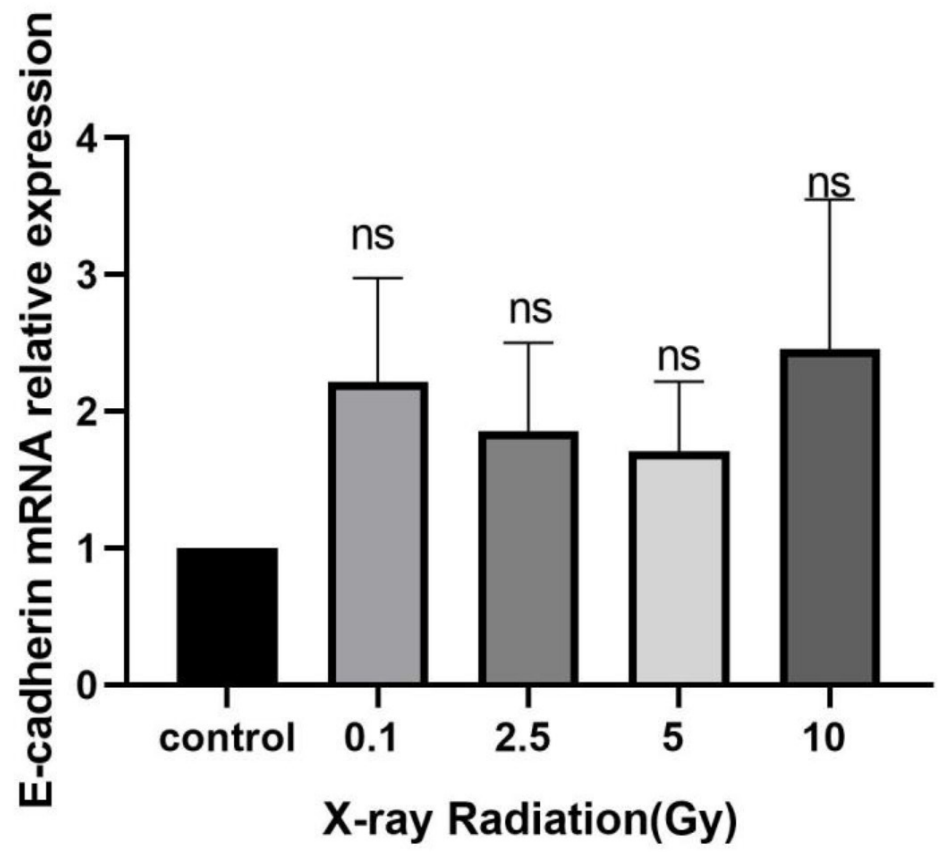

Figure 2: Expression of E-cadherin gene after irradiation of HT-29 cells with different single doses $(0.1,2.5,5$ and $10 \mathrm{~Gy})$ of X-ray. Total RNA was extracted after $20 \mathrm{~h}$ and analyzed for mRNA level of E-cadherin gene. Gene expression values obtained from irradiated cells were compared with control group which was standardized to a value of 1 . The experiments were performed at least three times in duplicate and results were presented as mean foldchange \pm SD.

ers who have observed increased expression of E-cadherin in post-irradiated cancer cells. Owing to this difference, the current study was planned to investigate the effect of different radiation doses on changes occurring in the expression of E-cadherin gene in colorectal cancer cell line HT-29.

Our results indicated that the expression of E-cadherin, due to various radiation doses of $\mathrm{X}$-ray (including $0.1,2.5,5$ and $10 \mathrm{~Gy}$ ), enhanced, although compared to control group, it was not statistically significant. In consistent with this result, Akimoto et al., reported that the expression of E-cadherin did not change significantly at earlier times of 1 and $3 \mathrm{~h}$ after exposing lung cancer cells (A549 cell line) into 10 Gy of X-ray [17]; however, they found that the expression of E-cadherin increased $24 \mathrm{~h}$ after various doses of X-ray (2-15 Gy) in the same cell line (A549) [17]. The same result was reported by Ebara et al., in postirradiated T-SCC cells (human squamous cell carcinoma) after different doses of 2-10 Gy of X-ray [18].

Tahmasebi et al., demonstrated that the expression of E-cadherin gene did not change significantly after irradiating A549 cells. However, in contrast to our result, they observed that the expression of E-cadherin gene decreased in HT-29 cell line. Regarding the two different irradiation regimens used in the two studies, different changes in E-cadherin gene expression in HT-29 cell line, may be explained. We irradiated the cells with single doses of $0.1,2.5,5$, and $10 \mathrm{~Gy}$, while, they applied fractionated irradiation regimen (cumulative doses of 10 and 20 Gy with 2 Gy/day fractions) [19]. There are more evidence that 
fractionated radiation has rendered reduced expression of E-cadherin gene. In a study carried out by Zhang et al., doses of $20 \mathrm{~Gy}$ ( $1 \mathrm{~Gy} /$ day and 2 Gy/day) and greater induced epithelial-mesenchymal transition and reduced the expression of E-cadherin gene in breast cancer cells [22]. Downregulation of E-cadherin expression after fractional radiation with a total dose of 75 Gy has also been reported in cervical cancer cell lines [20].

Although our data show no significant changes in the expression of E-cadherin, it does not necessarily mean that radiation does not promote invasiveness and metastatic potential in cancer cells, due to the fact that the change of E-cadherin gene is not the just activator of cell migration and invasion. Moreover, according to Ikeguch et al., and Akimoto et al., there is a complex process behind the expression of Ecadherin in metastatic foci of colorectal cancer cells, which might lead to E-cadherin overexpression with negative function [17-27]. In addition, according to molecular studies, Wnt/ $\beta$ catenin, STAT3 and ZEB1 are reported as the most important signaling pathways associated with E-cadherin expression in colorectal cancer cells $[12,28]$. Therefore, it is necessary to carry out more studies to investigate the effect of radiation dose on these signaling pathways.

\section{Conclusion}

Current study demonstrated that different doses of X-ray did not change the expression of E-cadherin in HT-29 colorectal cancer cells. However, to investigate whether radiation can promote tumor progression, invasion and metastasis in cancer cells through dysregulation of adhesion molecules, examining the effect of dose radiation on the expression of cadherins ( $\mathrm{P}$ and $\mathrm{N}$-cadherins) and catenins $(\alpha, \beta$ and $\gamma$ catenins), as the major components for E-cadherin function, needs to be conducted in future work.

\section{Acknowledgment}

The authors acknowledge the support for a
MSc. degree grant (No. 17247) from Shiraz University of Medical Science and Mashhad University of Medical Sciences.

\section{Conflict of Interest}

None

\section{References}

1. Bray F, Ferlay J, Soerjomataram I, Siegel RL, Torre LA, Jemal A. Global cancer statistics 2018: GLOBOCAN estimates of incidence and mortality worldwide for 36 cancers in 185 countries. CA: A Cancer Journal for Clinicians. 2018;68(6):394-424. doi: 10.3322/caac.21492. PubMed PMID: 30207593.

2. Zare-Bandamiri $M$, Fararouei $M$, Zohourinia $S$, Daneshi N, Dianatinasab M. Risk factors predicting colorectal cancer recurrence following initial treatment: a 5-year cohort study. Asian Pacific Journal of Cancer Prevention. 2017;18(9):2465. doi: 10.22034/APJCP.2017.18.9.2465.

3. Kawamoto A, Yokoe T, Tanaka K, Saigusa S, Toiyama $\mathrm{Y}$, Yasuda $\mathrm{H}$, Inoue $\mathrm{Y}$, Miki $\mathrm{C}$, Kusunoki M. Radiation induces epithelial-mesenchymal transition in colorectal cancer cells. Oncology Reports. 2012;27(1):51-7. doi: 10.3892/or.2011.1485.

4. Lagadec C, Vlashi E, Della Donna L, Dekmezian $C$, Pajonk F. Radiation-induced reprogramming of breast cancer cells. Stem Cells. 2012;30(5):83344. doi: 10.1002/stem.1058. PubMed PMID: 22489015. PubMed PMCID: PMC3413333.

5. Madani I, De Neve W, Mareel M. Does ionizing radiation stimulate cancer invasion and metastasis? Bull Cancer. 2008;95(3):292-300. doi: 10.1684/ bdc.2008.0598. PubMed PMID: 18390409.

6. Moncharmont C, Levy A, Guy JB, Falk AT, et al. Radiation-enhanced cell migration/invasion process: a review. Critical Reviews in Oncology/Hematology. 2014;92(2):133-42. doi: 10.1016/j.critrevonc.2014.05.006. PubMed PMID: 24908570.

7. Young $A G$, Bennewith KL. Ionizing radiation enhances breast tumor cell migration in vitro. Radiation Research. 2017;188(4):381-91. doi: 10.1667/ RR14738.1. PubMed PMID: 28763286.

8. Zhang $H$, Luo $H$, Jiang Z, Yue J, Hou Q, Xie R, Wu S. Fractionated irradiation-induced EMT-like phenotype conferred radioresistance in esophageal squamous cell carcinoma. Journal of Radiation Research. 2016;57(4):370-80. doi: 10.1093/jr/ rrw030. PubMed PMID: 27125498. PubMed PMCID: PMC4973649.

9. Baluna RG, Eng TY, Thomas Jr CR. Adhesion molecules in radiotherapy. Radiation Research. 
Radiation Dose and E-cadherin Expression

2006;166(6):819-31. doi: 10.1667/RR0380.1. PubMed PMID: 17149971.

10. Birchmeier W, Behrens J. Cadherin expression in carcinomas: role in the formation of cell junctions and the prevention of invasiveness. Biochimica et Biophysica Acta (BBA)-Reviews on Cancer. 1994;1198(1):11-26. doi: 10.1016/0304419x(94)90003-5. PubMed PMID: 8199193.

11. Van Roy F, Berx G. The cell-cell adhesion molecule E-cadherin. Cellular and Molecular Life Sciences. 2008;65(23):3756-88. doi: 10.1007/s00018-0088281-1. PubMed PMID: 18726070.

12. Batlle E, Sancho E, Francí C, Domínguez D, Monfar M, Baulida J, De Herreros AG. The transcription factor snail is a repressor of $\mathrm{E}$-cadherin gene expression in epithelial tumour cells. Nature Cell Biology. 2000;2(2):84-9. doi: 10.1038/35000034. PubMed PMID: 10655587.

13. Christofori G, Semb H. The role of the cell-adhesion molecule E-cadherin as a tumour-suppressor gene. Trends in Biochemical Sciences. 1999;24(2):73-6. doi: 10.1016/s0968-0004(98)01343-7. PubMed PMID: 10098402.

14. Marcucci F, Stassi G, De Maria R. Epithelial-mesenchymal transition: a new target in anticancer drug discovery. Nature Reviews Drug Discovery. 2016;15(5):311. doi: 10.1038/nrd.2015.13. PubMed PMID: 26822829.

15. Melissaridou S, Wiechec E, Magan M, Jain MV, Chung MK, Farnebo L, Roberg K. The effect of 2D and $3 \mathrm{D}$ cell cultures on treatment response, EMT profile and stem cell features in head and neck cancer. Cancer Cell International. 2019;19(1):16. doi: 10.1186/s12935-019-0733-1. PubMed PMID: 30651721. PubMed PMCID: PMC6332598.

16. Berx G, Van Roy F. The E-cadherin/catenin complex: an important gatekeeper in breast cancer tumorigenesis and malignant progression. Breast Cancer Research. 2001;3(5):289. doi: 10.1186/ bcr309. PubMed PMID: 11597316. PubMed PMCID: PMC138690.

17. Akimoto T, Mitsuhashi N, Saito $\mathrm{Y}$, Ebara T, Niibe $\mathrm{H}$. Effect of radiation on the expression of E-cadherin and $\alpha$-catenin and invasive capacity in human lung cancer cell line in vitro. International Journal of Radiation Oncology Biology Physics. 1998;41(5):1171-6. doi: 10.1016/s03603016(98)00176-x. PubMed PMID: 9719129.

18. Ebara T, Mitsuhashi N, Saito Y, Akimoto T, Niibe H. Change in E-cadherin expression after $\mathrm{X}$-ray irradiation of a human cancer cell line in vitro and in vivo. Int J Radiat Oncol Biol Phys. 1998;41(3):669-74. doi: 10.1016/s0360-3016(98)00096-0. PubMed
PMID: 9635718.

19. Tahmasebi-Birgani MJ, Teimoori A, Ghadiri A, Mansoury-Asl H, Danyaei A, Khanbabaei H. Fractionated radiotherapy might induce epithelialmesenchymal transition and radioresistance in a cellular context manner. Journal of Cellular Biochemistry. 2019;120(5):8601-10. doi: 10.1002/ jcb.28148. PubMed PMID: 30485518.

20. Yan S, Wang Y, Yang Q, Li X, Kong X, Zhang N, Yuan C, Yang N, Kong B. Low-dose radiation-induced epithelial-mesenchymal transition through $\mathrm{NF}-\mathrm{\kappa B}$ in cervical cancer cells. International Journal of Oncology. 2013;42(5):1801-6. doi: 10.3892/ ijo.2013.1852. PubMed PMID: 23483258.

21. Zang C, Liu X, Li B, He Y, Jing S, He Y, Wu W, Zhang B, Ma S, Dai W, Li S. IL-6/STAT3/TWIST inhibition reverses ionizing radiation-induced EMT and radioresistance in esophageal squamous carcinoma. Oncotarget. 2017;8(7):11228. doi: 10.18632/oncotarget.14495. PubMed PMID: 28061440. PubMed PMCID: PMC5355260.

22. Zhang X, Li X, Zhang N, Yang Q, Moran MS. Low doses ionizing radiation enhances the invasiveness of breast cancer cells by inducing epithelial-mesenchymal transition. Biochemical and Biophysical Research Communications. 2011;412(1):188-92. doi: 10.1016/j.bbrc.2011.07.074. PubMed PMID: 21810413.

23. Kim RK, Cui YH, Yoo KC, Kim IG, Lee M, Choi $\mathrm{YH}$, Suh Y, Lee SJ. Radiation promotes malignant phenotypes through SRC in breast cancer cells. Cancer Science. 2015;106(1):78-85. doi: 10.1111/ cas.12574. PubMed PMID: 25533622. PubMed PMCID: PMC4317785.

24. Kim RK, Kaushik N, Suh Y, Yoo KC, Cui YH, Kim MJ, Lee HJ, Kim IG, Lee SJ. Radiation driven epithelial-mesenchymal transition is mediated by Notch signaling in breast cancer. Oncotarget. 2016;7(33):53430. doi: 10.18632/oncotarget.10802. PubMed PMID: 27462787. PubMed PMCID: PMC5288197.

25. Christou N, Perraud A, Blondy S, Jauberteau MO, Battu S, Mathonnet M. E-cadherin: A potential biomarker of colorectal cancer prognosis. Oncology Letters. 2017;13(6):4571-6. doi: 10.3892/ ol.2017.6063. PubMed PMID: 28588719. PubMed PMCID: PMC5452924.

26. Theys J, Jutten $B$, Habets R, Paesmans K, Groot AJ, Lambin P, Wouters BG, Lammering G, Vooijs M. E-Cadherin loss associated with EMT promotes radioresistance in human tumor cells. Radiotherapy and Oncology. 2011;99(3):392-7. doi: 10.1016/j. radonc.2011.05.044. PubMed PMID: 21680037. 
Soleymanifard Sh. et al

PubMed PMCID: PMC4948667.

27. Ikeguchi M, Makino M, Kaibara N. Clinical significance of E-cadherin-catenin complex expression in metastatic foci of colorectal carcinoma. Journal of Surgical Oncology. 2001;77(3):201-7. doi: 10.1002/jso.1095. PubMed PMID: 11455558.

28. Xiong H, Hong J, Du W, Lin YW, Ren LL, Wang
YC, Su WY, Wang JL, Cui Y, Wang ZH, Fang JY. Roles of STAT3 and ZEB1 proteins in E-cadherin down-regulation and human colorectal cancer epithelial-mesenchymal transition. Journal of Biological Chemistry. 2012;287(8):5819-32. doi: 10.1074/ jbc.M111.295964. PubMed PMID: 22205702. PubMed PMCID: PMC3285352. 